\title{
Pathological and Immunohistochemical Examinations on Co-Infection with Coligranulomatosis and Marek's Disease in a Turkey Flock
}

\author{
Mehmet Burak Ateş̧, ${ }^{1, a}$ Zeynep Çelik ${ }^{1, b, *}$, M. Kemal Çiftçi ${ }^{1, c}$ \\ ${ }^{I}$ Department of Pathology, Veterinary Faculty, University of Selcuk, 42130 Selcuklu, Konya, Turkey
} ${ }^{*}$ Corresponding author

\section{A R T I C L E IN F O}

Research Article

Received : 28/05/2020

Accepted : 21/12/2020

Keywords: Coligranuloma (Hjarre's disease) Histopathology Immunohistochemistry

Marek's disease

Turkey

\section{A B S T R A C T}

Coligranulomatosis, which induces hepatic granulomas, and Marek's disease, one of the important neoplastic diseases in poultry, rarely causes outbreaks in turkeys. In this study, etiological diagnoses were performed in the light of post-mortem, histopathological, microbiological, and immunohistochemistry studies of turkeys that died in a commercial establishment in the region of Konya. In the post-mortem examination, many grey-white foci with a diameter of 3-10 $\mathrm{mm}$, which sometimes spread from serosa to the parenchyma, were found in the liver. Mucous exudate and hyperemia were detected in all segments of the intestine. For microscopic examination, all tissues were stained with Haematoxylin-Eosin and some selected liver tissues with Periodic Acid-Schiff, Ziehl-Neelsen, and Giemsa. Typical structures of pyogranulomas with an eosinophilic necrotic core in the liver were identified. Tumor foci formed by pleomorphic histiocyte and lymphoid cells were also observed in the liver, spleen, and intestines (jejunum and cecum). In the selected liver and intestinal sections, a positive reaction was obtained in tumor cells in immunohistochemical staining with the primary antibody specific for Marek's disease virus. In addition, Escherichia coli isolation was performed microbiologically in swaps and samples taken from lesioned areas of the liver. As a result of the examinations, other etiological agents that may cause hepatic granulomas in the turkeys were excluded, and coligranulomatosis and Marek's disease were diagnosed simultaneously in this turkey flock. It was concluded that in cases in which these two diseases are observed simultaneously, the diseases might interact with each other, and casualties may increase.

Tavukçuluk Araştırma Dergisi 17(2): 87-95, 2020

\section{Bir Hindi Sürüsünde Eş Zamanlı Koligranülomatozis ve Marek Hastalığı Üzerine Patolojik ve İmmunohistokimyasal İncelemeler}

\begin{tabular}{l} 
M A K A L E B İ L G \\
\hline Araştırma Makalesi \\
\\
Geliş $\quad: 28 / 05 / 2020$ \\
Kabul $\quad: 21 / 12 / 2020$
\end{tabular}

Anahtar Kelimeler: Koligranüloma (Hjarre's hastalığ 1 ) Histopatoloji İmmunohistokimya Marek hastalığ 1 Hindi

\section{Ö Z}

Kanatlılarda hepatik granülomlara neden olan Koligranülomatozis ve önemli neoplastik hastalıklarından biri olan Marek, hindilerde nadiren salgınlara neden olan hastalıklardır. Bu çalışmada Konya bölgesinde ticari bir hindi işletmesinde ölen hindilerin post-mortem, histopatolojik, mikrobiyolojik ve immunohistokimyasal incelemeleri 1şığında etiyolojik tanıları yapılmıştır. Post-mortem muayenede karaciğerde parankime yayılan çok sayıda 3-10 mm çapında gri-beyaz renkli odaklara rastlanıldı. Bağırsakların tüm sekmenlerinde mukuslu eksudat ve hiperemi belirlendi. Mikroskobik muayene için tüm dokular Hematoksilen-Eozin, seçilen bazı karaciğer dokuları ise Periodic acid-Schiff, Ziehl-Neelsen ve Giemsa ile boyandı. Karaciğerde, ortalarında eizonofilik bir nekrotik kitle bulunan tipik piyogranülom yapıları belirlendi. Ayrıca karaciğer, dalak ve bağırsaklarda (jejenum ve sekum) pleomorfik histiyosit ve lenfoid hücrelerin oluşturduğu tümör odakları gözlendi. Seçilen karaciğer ve bağırsak kesitlerine Marek hastalığı virüsüne spesifik primer antikorla yapılan immunohistokimyasal boyamalarda tümör hücrelerinde pozitif reaksiyon elde edildi. Ayrıca karaciğerde lezyonlu bölgelerden alınan swap ve örneklerde mikrobiyolojik ekim sonucu Escherichia coli izolasyonu gerçekleștirildi. Yapılan incelemeler sonucunda, hindilerde hepatik granülomlara neden olabilecek diğer etiyolojik ajanlar da dışlanarak, bu hindi sürüsünde eş zamanlı olarak seyreden koligranülomatozis ve Marek hastalığı teşhisi konuldu. Bu hastalıkların birbiri ile etkileşim gösterebileceği ve iki hastalığın aynı anda gözlendiği olgularda ölüm vakalarının artabileceği sonucuna varıldı. 


\section{Introduction}

Coligranulomatosis (Hjarre's disease, coligranuloma) is a sporadic disease caused by Escherichia coli (E. coli), a gram-negative bacillus, and characterized by the formation of granulomas in the liver, intestine, and mesenterium in chickens and turkeys (Barnes and Vaillancourt, 2008). The disease was first described by Hjarre and Wramby in 1945 (Hjarre and Wramby 1945; Schofield, 1947; Trylich, 1966). In the following years, it was diagnosed by many researchers in different herds. The first notification in turkeys was made in 1947 by Schofield in Canada (Schofield, 1947). Then, between 1962-1963, approximately 2000 turkeys were affected by the disease in Canada (Trylich, 1966). Although the disease is relatively sporadic, it can reach up to $75 \%$ mortality in chicken herds but the mortality in turkey herds is not well known (Barnes and Vaillancourt, 2008; Landman et al., 2017). Although the pathogenesis of the disease is not fully known, the transmission is thought to be through respiratory, digestive, and skin (Supartika et al., 2006). Clinical symptoms in poultry suffering from coligranulomatosis have been reported as depression, nasal discharge, sneezing, ruffled feathers and yellowish or white defecation. Macroscopically, the lesions are usually in the serosa of the organs mentioned, but sometimes they may have spread to the parenchyma. (Supartika et al., 2006). These lesions in serosa resemble tuberculosis lesions and tumoral foci seen in leucosis (Barnes and Vaillancourt, 2008; Islam et al 2007; Schofield, 1947; Trylich, 1966). Microscopically, there is a pink necrosis in the center, lymphocyte, plasma cells, macrophages, epithelioid cells and heterophile infiltrations around it, and pyogranuloma formations surrounded by fibrous connective tissue at the outermost part (Islam et al 2007; Schofield, 1947; Supartika et al., 2006). Pathological findings are essential in diagnosis and the disease should be differentiated from tuberculosis, Tetratrichomonas gallinarum and Histomonas meleagridis (Islam et al 2007; Landman et al., 2017; Trylich, 1966). The most commonly used method in the diagnosis of the disease is the culture method and it is stated to be an important method for diagnosis (Rahimi et al., 2014).

Marek's disease (MD) is a common lymphoproliferative disease characterized by infiltration of polymorphic small and big size lymphocytes in various organs and tissues (Çiftçi et al., 2011; Nair et al., 2020; Yavuz and Erer, 2017). The causative agent is the Marek Disease Virus (MDV) from the Herpesviridae family, it is highly contagious and the disease must be etiologically distinguished from other lymphoproliferative neoplastic diseases in poultry (Biggs and Nair, 2012).

In turkeys, this type of neoplastic diseases may be caused by MDV, Avian leukosis virus, Reticuloendotheliosis virus, or Lymphoproliferative disease virus (Calnek et al., 1970; Pennycott and Venugopal, 2002). Tumors caused by MDV are common in chickens and have been subject to extensive research so far, but have received less attention as they are rare in turkeys (Nair et al., 2020). It has been reported that the mortality rate between $8-19$ weeks in experimental infections can reach between 22-70\% (Davidson et al., 2002; Nair et al., 2020; Paul et al., 1977). In addition, in turkeys with tumor development, an increase in susceptibility to diseases was determined as a result of immunosuppression (Elmubarak et al., 1981; Nair et al., 2020). In chickens, neural involvement is often observed, characterized by pleomorphic lymphocyte infiltrations, which may result in macroscopically thickening of the peripheral nerves, however, these neural involvement and nerve lesions are not frequently observed in turkeys (Powell et al., 1984). In experimental studies, the lesions seen in the nerves were either rarely encountered or not at all. However, it has been noted that lymphoproliferative lesions occurring in visceral organs in chickens are also seen in turkeys (Hughes et al., 2016; Nair et al., 2020). In the acute form, while pleomorphic lymphocyte deposits were observed in the visceral organs, it was reported that clinical findings were less pronounced, in this case, deaths could increase rapidly and reach $70 \%$ in large outbreaks (Nair et al., 2020). However, it has been noted that these lesions are not as common or apparent in turkeys as in chickens, both macroscopically and microscopically (Blake-Dyke and Baigent, 2013; Deuchande et al., 2012; Nair et al., 2020). Marek's disease in turkeys can be confused with reticuloendotheliosis and poultry leucosis, as in chickens (Nair et al., 2020). Therefore, besides histopathology, diagnostic methods such as PCR and IHC, especially for the demonstration of specific antibodies, should be used in the differential diagnosis (Davidson et al.,2002; Haridy et al., 2009).

Marek's disease remains a major problem in the poultry industry due to unforeseen outbreaks (Nair et al., 2020). Coligranuloma, on the other hand, is a disease that can cause large outbreaks, especially due to poor care, feeding, and immunosuppression (Islam et al 2007; Rahimi et al., 2014). The lack of specific findings in both diseases causes incorrect diagnosis and treatments and economic losses in the turkey flocks. To the best of our knowledge, there is no study investigating the co-infections of coligranuloma and Marek's disease together. For this reason, in this study, it was aimed to investigate the interaction between the two diseases by conducting pathological examinations on coinfection with coligranuloma and Marek's disease in a turkey herd.

\section{Material and Method}

\section{Animals}

In this research, 30, 3-4 months old turkeys which died in a commercial turkey herd in the Konya region were used. In October 2019, a post-mortem examination request was made to the Selcuk University Veterinary Faculty Pathology department. It was reported that 80 deaths occurred in the last 2 weeks in only a section of the farm growing unit and etiological diagnosis could not be made in post-mortem examinations. It was stated that there were 5 sections in the breeding unit of this farm and 200 turkeys were fed in each section. Anorexia, depression, anormal inability to stand up, sneezing, breathing problems, and sometimes yellowish-white diarrhea were mentioned in sick animals in the affected compartment. Besides, one animal from each of the remaining four healthy compartments was euthanized for post-mortem 
examination and other analyses. It was also stated that the Marek's disease vaccine was not applied to the flock. During the time elapsed from necropsy to diagnosis, it was informed that the turkeys continued to die and the remaining animals in the section where the disease was found were sent to the slaughter.

\section{Histopathological Method}

Macroscopic findings of the parenchymatous organs were recorded after performing systematic necropsies of all animals. During necropsy, samples from these tissues were fixed in $10 \%$ buffered formalin solution for 48 hours. All tissues were embedded in paraffin after routine tissue processing processes (Leica TP 1020). Then, five- micron thick sections were taken into the microtome (Leica RM2125 RT). These sections were examined with light microscopy after staining with hematoxylin-eosin (H.E.) (Luna, 1968). After this examination, ten liver tissues with granulomatous lesions were selected and additional specific stainings were performed.

\section{Microbiological Method}

Isolation of the bacteria in culture from the collected tissue samples were made by using Mac Conkey agar and EMB (Eosin Methylene Blue), then colony and staining characteristics were noted. While bright pink colonies with precipitates were observed on Mac Conkey agar, dark colonies with metallic sheen were detected on EMB agar. Also biochemical tests including indol, methyl red, VogesProskauer and citrate tests (IMViC tests) were conducted. and the results of the tests were recorded $(+/+/-/-)$ respectively.

\section{Periodic Acid-Schiff Stain}

The sections taken from the liver were stained with Periodic acid-Schiff (PAS) to detect fungi and Histomonas meleagridis (Clarke, 2017; Kemp and Reid, 1966). After the sections were deparaffinized, they were left in $0.5 \%$ periodic acid solution for 5 minutes. The sections were washed in distilled water and immersed in Schiff reagent (Sigma-Aldrich, Germany) for 15 minutes. These were washed with tap water for 5 minutes, counterstain was performed in Mayer's hematoxylin (Novocastra, Leica, USA) then dehydrated and closed with Entellan (Merck Millipore, Germany) (Luna, 1968).

\section{Ziehl-Neelsen Stain}

Ziehl-Neelsen staining was performed on selected liver samples to identify acid-fast bacteria (Supartika et al., 2006). The sections were deparaffinized with alcohol and xylene. After being stained in carbol-fuchsin solution (Sigma-Aldrich, Germany) (30 min), they were decolorized in acid alcohol. The sections were rinsed in running tap water and contrast stained in methylene blue solution (Sigma-Aldrich, Germany) (3 min.) Dehydrated in 95\% and absolute alcohol, the sections were kept in xylol and then closed with Entellan (Merck Millipore, Germany) (Luna, 1968).

\section{Giemsa Stain}

Giemsa staining was performed to determine the Tetratrichomonas gallinarum in the sections and smear samples obtained from the lesioned livers (Friedhoff et al.,
1991; Landman et al., 2016). First, the tissue sections were deparaffinized. Both smear samples and tissue sections were fixed in methyl alcohol. Samples were kept in the Jenner solution (Sigma-Aldrich, Germany) for 5 minutes. Then these were stained with Giemsa (Sigma-Aldrich, Germany) for 45 minutes and differentiated in acidic water. These sections were washed in tap water and then dehydrated in alcohol. Finally, these were immersed in xylol and closed with permount (Fisher Chemical, USA).

\section{Immunohistochemical Method}

It was observed that the lymphoproliferative lesions determined after histopathological examinations were mostly concentrated in the liver and small intestines (jejunum). Ten liver and intestine specimens with these lesions were selected for immunohistochemical analysis. Five-micron thick sections were stained in a fully automated Bondmax (Leica, USA) immunohistochemistry staining device by the procedure of the Bond TM polymer refine detection kit (Leica DS9800) (peroxidase block, protein block, post primer, polymer, DAB, hematoxylin).

First, all tissues were deparaffinized with heat and dewax solution and rehydrated in alcohol. The sections were washed at least 3 times after each step with separate washing solution (Bond TM, Leica, AR9590) and deionized water. Then, heat-induced epitope retrieval (HIER), (epitope 1 antigen retrieval solution, Bond TM, Leica, AR9961, citrate buffer Ph: $6.0,100{ }^{\circ} \mathrm{C}-20 \mathrm{~min}$.) was applied to the sections of tissue. Peroxidase block (30 min.) was used to remove the peroxidase activity and protein block (30 min.) was applied to prevent non-specific adhesions. Post-primary and polymer applications were made to the sections after a one-hour reaction with Marek's disease virus-specific antibody (anti-Marek's disease virus antibody, ab90487, 1:100, Abcam, USA) (Yavuz and Erer, 2017) at room temperature. Subsequently, all sections were incubated with DAB for $5 \mathrm{~min}$. at room temperature. After the sections were washed with distilled water, contrast staining was performed with Mayer's hematoxylin. The sections were examined under the light microscope (Olympus BX51, Tokyo, Japan) and photographed (Olympus EP50).

\section{Results}

\section{Macroscopic Findings}

In necropsy, five turkeys were not evaluated because of autolysis. Macroscopically, abnormal findings were detected in the liver and intestine segments of all turkeys. The livers were moderately enlarged and exhibited thickening at the edges. Numerous grey-white foci from pinhead to chickpea size were found on the liver. It was determined that these foci spread towards parenchyma and were 3-10 $\mathrm{mm}$ in diameter (Figure 1). A slight enlargement was observed in the spleens (16 of 25) and kidneys (19 of 25) without a nodular structure. Hyperaemia and mucous exudate were detected in all segments of the intestine. Other organs including nerves were observed to be within normal limits macroscopically. Also, macroscopic findings were not found in turkeys from healthy compartments. 


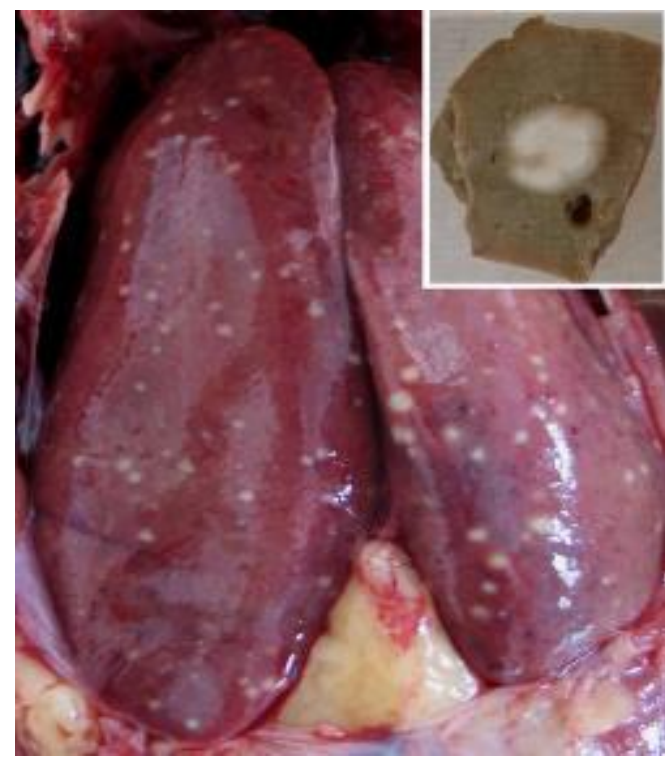

Figure 1. Macroscopic examination of the liver, numerous grey-white foci from pinhead to chickpea size. Inset: Necrotic focus on the sectional side of the liver.

\section{Microscopic Findings}

Many solitary, multiple, and combined pyogranulomas were found in the liver of all turkeys. In the middle of these, an eosinophilic necrotic core was identified. A dense cellular zone formed by lymphocyte, heterophile granulocyte, epithelioid histiocytes, and giant cells was determined around this necrosis. It was observed that this structure was surrounded by a thin capsule consisting of connective tissue (Figure 2A-C). Besides, multifocal necroses spread to the liver parenchyma were recorded in 16 cases (Figure 2D-E). Apart from these, a small number of histiocyte and pleomorphic lymphoid cell proliferation in the liver, spleen, and/or intestinal segments were found in 21 of the 25 turkeys (Figure 2F) (Figure 3A-B, E). It was observed that these tumor foci did not appear to spread to organs, were limited in number, and their mitotic activity was low. There was also an intense basophilic image in the cells in these foci. In the intestines of all turkeys, degeneration and desquamation in epithelial cells and mononuclear and heterophil cell infiltration in the propria layer were observed. Atrophy and lymphoid depletion were detected in the spleen lymphoid tissue in all turkeys. There was slight hydropic degeneration in the tubular epithelium in kidneys. In other tissues, no microscopic findings were found. Also, mild catarrhal enteritis was detected in only one of the turkeys in the healthy compartment. Liver samples with granulomas were stained with Ziehl-Neelsen, PAS, and Giemsa to detect acid-resistant bacteria, Histomonas meleagridis, Tetratrichomonas gallinarum, respectively.

However, no positive staining could be obtained either inside or around the granulomas. Also, indications of the presence of these agents were not found in the H.E. stain. Parasitological examinations reported that no parasites or protozoa were observed. Bacteriological examinations showed that no agent other than flora bacteria were produced in the intestines, but $E$. coli was cultured from all the liver samples.

\section{Immunohistochemical Findings}

In all selected liver and intestinal samples, positive reactions were obtained by immunohistochemical staining (IHC) using antibodies specific to Marek's disease virus (MDV). Immunopositive reactions were observed in the cytoplasm and nuclei of lymphocytes and histiocytes in the lymphoproliferative lesions in the liver and intestine (Figure 2F-H, Figure 3C-D, F). No positive immunoreactivity was found in both pyogranulomas and multifocal necrosis in the liver parenchyma. Also, it was determined that MDV spread more in the intestinal segments compared to other organs and positive immunoreactivity was determined in some intestinal epithelial cells.

\section{Discussion and Conclusion}

Coligranuloma (Hjarre's disease or coligranulomatosis) of chickens and turkeys is a sporadic but important form of systemic colibacillosis and can cause up to $75 \%$ mortality in herd outbreaks (Chauhan, 2003). Marek's disease, which can cause tumors in poultry, leads to death in some cases and can also reduce yield and depress the immune system, increasing susceptibility to diseases (Nair et al., 2020). The relationship of Marek's disease with E. coli-induced coligranulomatosis is an obscure issue. In the present study, we examined the coligranulomatosis and Marek's disease in a turkey herd considering the aetiologic agents that may be confused in the differential diagnosis, and we described the macroscopic, microscopic and immunohistochemical findings.

Clinical findings have been reported not specific in poultry with liver granuloma (Coles, 1985). In the macroscopic examination, it has been mentioned that color changes can be seen next to hepatomegaly, and examination of granulomas in the liver will provide useful information in the differential diagnosis (Supartika et al., 2006). In our study, besides hepatomegaly, nodular structures that spread to the parenchyma and slightly protruded from the surface were observed in the livers. The middle of these nodules was not found to be caseified. It has been reported that poultry tuberculosis has caseified nodules that tend to spread to the spleen and bone marrow (Landman and van Eck 2017). In our findings, similar nodules were not seen in the bone marrow and spleen. With this aspect, it is partially differentiated from tuberculosis in the macroscopic examination. The histopathological structure of granulomas in the liver can be an indicator of the possible cause of the lesion. This can be useful for early diagnosis before a definitive diagnosis is made by isolation and identification of the etiological agent. Intense heterophile infiltration and micro or macro abscesses with the granulomatous environment have been reported to be associated with infections caused by bacteria (Supartika et al., 2006). In our study, the identification of typical pyogranulomas in which histopathologically determined heterophile infiltrations were intense, strengthened the opinion that these were bacterially sourced. Therefore, it was thought that these lesions determined in liver parenchyma might be coligranulomatosis due to $E$. coli. As also determined in the findings of our study, it was stated that macroscopically and microscopically observed granulomas in coligranulomatosis may be in the liver and intestines, but not in the spleen (Supartika et al., 2006). 

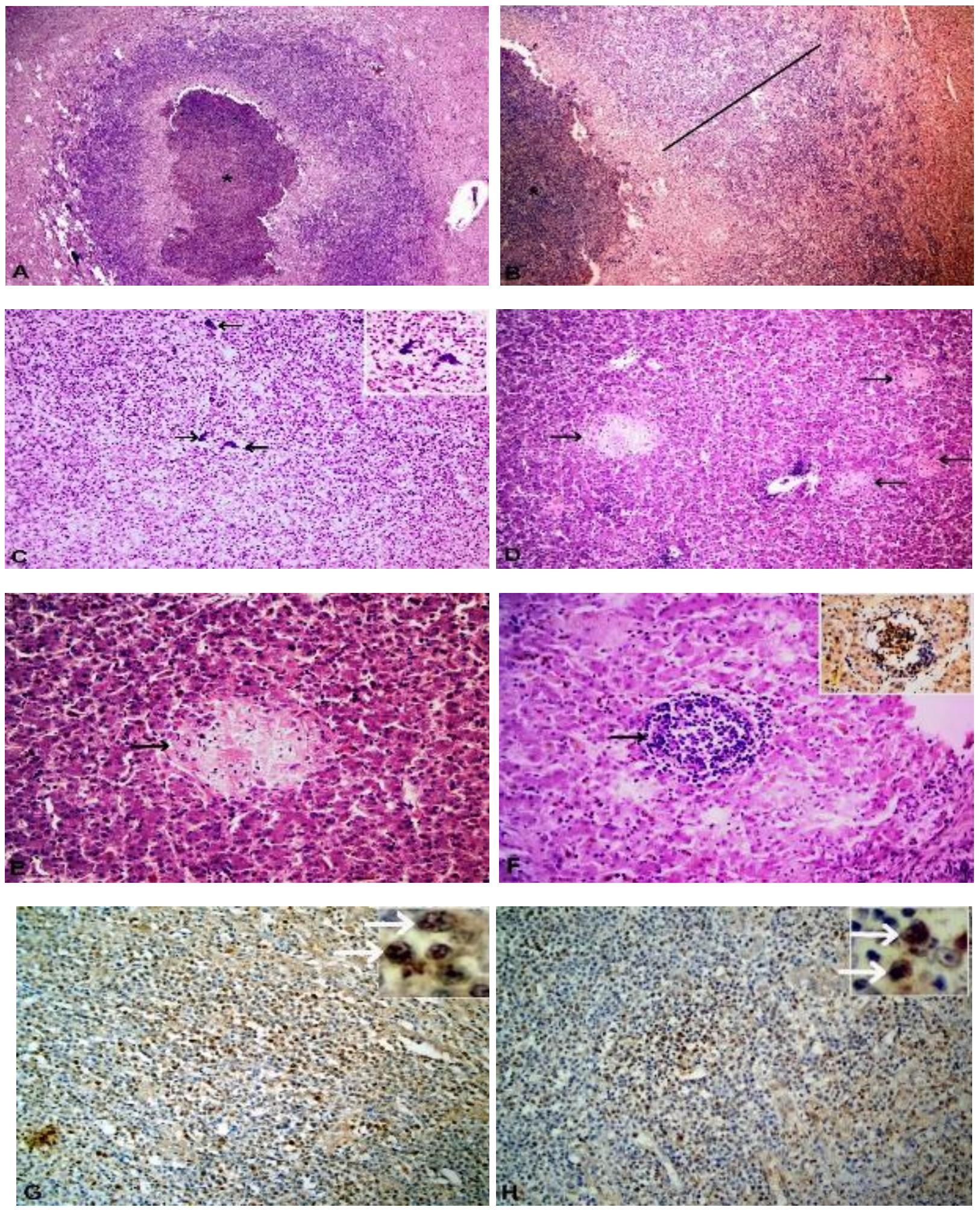

Figure 2. Histopathological and immunohistochemical examination photos, liver, A: General histopathological view of the pyogranuloma (asterisk; the necrotic center of the pyogranulomas), 4X, H.E., B: Inflammatory cell line and heterophile granulocyte infiltration (line) around the necrotic center (asterisk), 20X, H.E., C: Heterophil granulocyte, lymphocyte, plasma cell, histiocyte, epithelioid and giant cell infiltrations (arrows), Inset: Giant cells, 40X, H.E., D: Multifocal necrosis foci (arrows) spread in the parenchyma, 20X, H.E., E: Necrotic focus (arrow), 40X, H.E., F: Dense pleomorphic lymphoid infiltration (arrow), Inset: Marek's immunopositive reaction in this focus, 40X, H.E., IHC. G-H: Marek's positive immunoreactivity in the tumor cells, insets:

Marek's immunopositive cells 40X, IHC. 

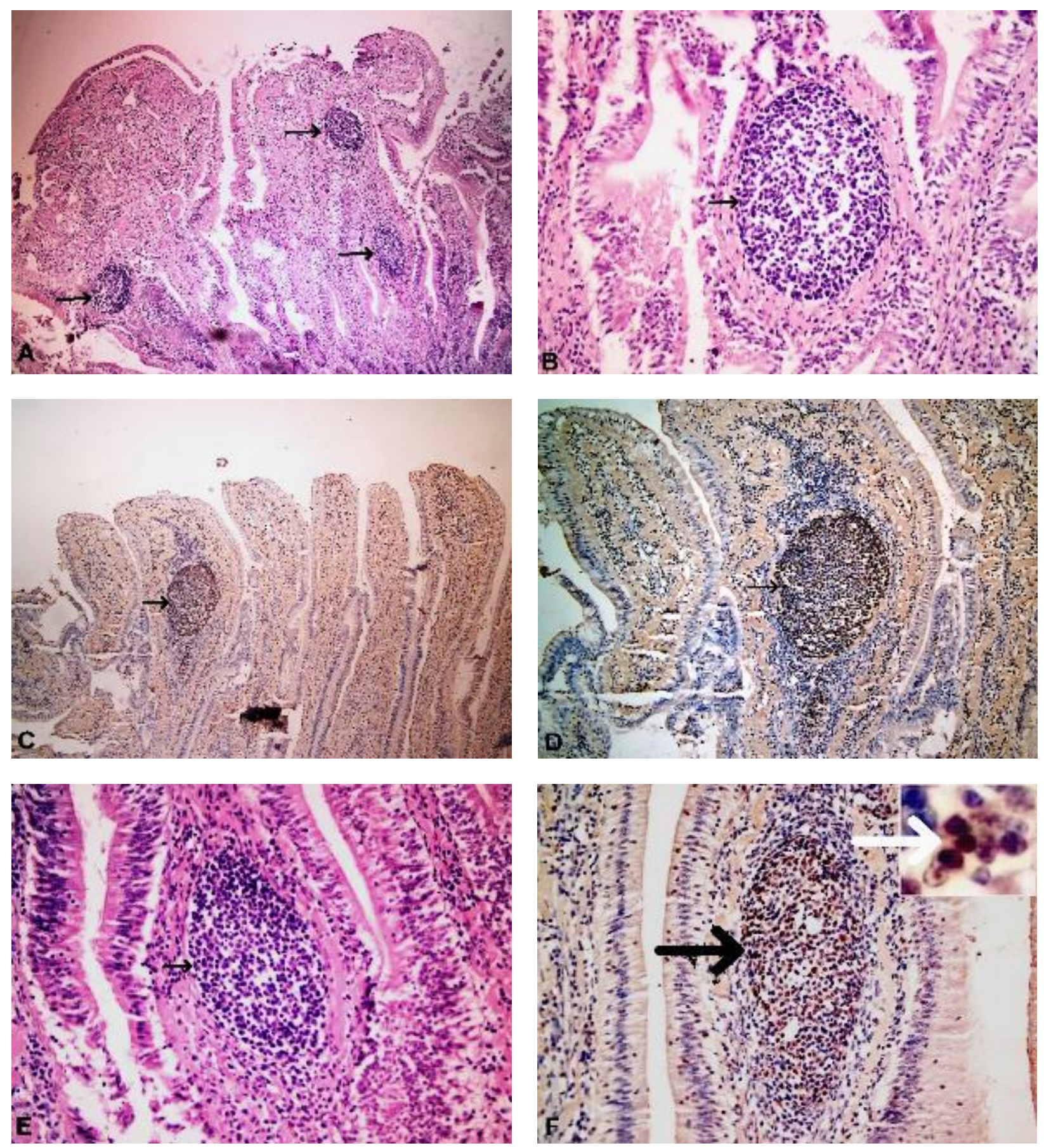

Figure 3. Histopathological and immunohistochemical examination photos, intestines. A: Degeneration and desquamations in the epithelium, inflammatory cell infiltration in the lamina propria, and Marek's foci formed by pleomorphic lymphoid cells (arrows), 10X, H.E. B: Lymphoid focus formed by pleomorphic lymphoid cells (arrow), 40X, H.E., C: Marek's positive immunoreactivity in the lymphoid focus (arrow), 10X, IHC, D: Marek's positive immunoreactivity in the lymphoid focus (arrow), 20X, IHC, E: Lymphoid focus formed by pleomorphic lymphoid cells (arrow), 40X, H.E., F: Marek's positive immunoreactivity in the lymphoid focus (arrow), inset:

Marek's immunopositive cells 40X, IHC.

However, differential diagnoses of poultry tuberculosis, histomoniasis, tetratrichomoniasis, and fungal diseases, which are other conditions where such similar granulomatous lesions may be seen, must be made (Landman and van Eck, 2017). Cases of coligranulomatosis have been reported to be sometimes confused with cases of tetratrichomoniasis (Landman and van Eck, 2017). In another study by the same author in chickens, protozoa or bacteria were not found in the histopathological examination of 184 liver and intestinal samples with granulomas. Even with special staining and fluorescence in situ hybridization technique to show the agents in lesions, only one positive was obtained. Despite this, and based on the Koch postulate, it was stated that these granulomas were originated by Tetratrichomonas gallinarum, although it was not shown in the lesions (Landman et al., 2016). However, this study has been criticized for this aspect (Liebhart and Hess, 2018). 
Because in other studies in poultry, it has been reported that necrotic lesions and granulomas due to Tetratrichomonas gallinarum have been diagnosed by showing them with histological and special staining (Liebhart and Hess, 2018; Liebhart et al., 2014; Patton and Patton, 1996; Richter et al., 2010). In our study, the presence of this agent could not be confirmed as a result of staining with H.E., Giemsa, or PAS method and as a result of parasitological examinations. Another disease frequently confused with coligranulomatosis is poultry tuberculosis (Rahimi and Siavash Haghighi, 2014; Supartika et al., 2006). In the Ziehl-Neelsen staining applied to different sections for the differential diagnosis, the presence of acid-resistant bacteria was not found. On the other hand, no positivity was found in PAS staining performed to investigate the presence of histomoniasis and fungi that may cause granulomatous inflammation in poultry. Culture has been stated to be the best method for the definitive etiological diagnosis of granulomas in poultry (Rahimi and Siavash Haghighi, 2014). As a matter of fact, in our study, isolation of $E$. coli was made as a result of bacterial culture made from swaps and samples taken directly from the lesioned area. As a result, coligranuloma diagnosis was made by excluding other agents to be mixed in the differential diagnosis in the light of special dyes and histopathological examinations. Besides, the macroscopic and microscopic findings determined in our study were consistent with the coligranuloma cases previously observed in turkey and other poultry (Islam et al., 2007; Rahimi and Siavash Haghighi, 2014; Ramesh et al., 2018; Trylich, 1966).

There are various discussions on coligranuloma in poultry. Landman and van Eck (2017), claim that coligranulomatosis is considered to be a chicken, turkey, and partridge disease that rarely occurs individually in adult poultry, and therefore it is not of economic importance but is interesting because its lesions are similar to tuberculosis lesions. They speculated that past coligranulomatosis diagnoses were incorrect on the grounds that the Koch-postulate could not be fulfilled and the conditions of causality were not realized. They suggested that the main factor in these cases was Tetratrichomonas gallinarum. It was reported that granulomas were formed by artificial inoculation (intramuscular, etc.) of $E$. coli, which was isolated from these cases, but granulomas did not occur when given orally. They saw this as the reason that past cases were not coligranulomatosis (Landman and van Eck, 2017). There are opposite views, like ours, that the etiology of coligranulomatosis does not need to be re-considered in poultry (Liebhart and Hess, 2018). This is because normal healthy poultry has been reported to be highly resistant to virulent E. coli strains (Nolan et al., 2020). E. coli related infections occur under stress factors such as the skin or mucosal barrier injury caused by viral, bacterial, parasitic agents, normal microbiota deficiency, mononuclear phagocytic system dysfunction, or immunosuppression (due to viral infection, etc.), and poor care-nutrition (Nolan et al., 2020). In the Koch-postulate, there is only a microbial perspective in which the host and environmental factors are disregarded (Haynes et al., 1997). We think that the results obtained from a model that excludes individual genetics, immune system, microbiota differences, exposure to stress and predisposing factors, and simultaneous infection will not be compatible with the scientific and modern epidemiological approach. Also, the past coligranuloma studies examined by Landman and van Eck (2017) did not exclude all the etiological causes that may cause hepatic granuloma in the liver, which may have caused authors to view these diagnoses suspiciously (Hamilton and Conrad, 1958; Landman and van Eck, 2017; Trylich, 1966; Trylich et al., 1977). On the other hand, culture being the best way to make a correct diagnosis of granuloma in poultry has been reported (Rahimi and Siavash Haghighi, 2014). In this regard, in our study, both the demonstration of the etiological agent in culture and making the differential diagnosis by excluding other causes provided the causality principle to a great extent, making the diagnosis of coligranuloma possible.

It is worth noting that cases related to coligranuloma in turkeys are very limited and the majority of them are not up to date (Trylich, 1966; Trylich, 1977). It has been reported that this disease, which is also mostly sporadic in other poultry species, may cause outbreaks from time to time, resulting in significant economic losses (Islam et al., 2007; Rahimi and Siavash Haghighi, 2014). Morbidity in turkeys is $32-51 \%$ but data of mortality was not reached (Landman and van Eck, 2017). Morbidity in chickens is $75-100 \%$, and mortality can reach up to $75 \%$ (Landman and van Eck, 2017). In our study, the rate of morbidity could not be determined because the remaining animals in the compartment containing 200 animals were sent to slaughter. However, since the number of deaths until the time that the dead animals were transferred to us was 110 , the mortality rate was determined as at least $55 \%$ for the section where the deaths took shape and $11 \%$ for the whole herd.

In our study, a histopathologically limited number of pleomorphic lymphoproliferative foci were detected in the liver, intestine, and spleen. It was determined that these tumor foci were concentrated in the intestines but did not show an intensive spread to other organs. In turkeys, this type of tumoral lesions may be caused by Marek's disease virus, Avian leukosis virus, Reticuloendotheliosis virus, or Lymphoproliferative disease virus (Pennycott and Venugopal, 2002). The immunohistochemical method has been indicated to be able to provide very useful information in the differential diagnosis (Haridy et al., 2009; Hughes et al., 2016; Yavuz and Erer, 2017). For this purpose, in IHC staining using MDV specific antibodies, immunopositive reactions were observed in the cytoplasm and nuclei of lymphocytes and histiocytes in tumor foci in the selected liver and intestine tissues. This staining model is consistent with other studies (Haridy et al., 2009; Wen et al., 2018; Yavuz and Erer, 2017).

While Marek's disease is common in chickens, it is much less common in turkeys (Hughes et al., 2016). Although histopathological changes in Marek's disease are well defined in chickens, limited findings have been reported in turkeys (Pennycott and Venugopal, 2002). It has been reported that the most characteristic histopathological finding is pleomorphic lymphocytes and mononuclear cells infiltration in multiple organs as in chicken (Hughes et al., 2016; Nair et al., 2020; Pattison et al., 2008). Nevertheless, it has been stated that macroscopic and microscopic findings observed in chickens are not frequently observed or not evident in turkeys (Blake-Dyke 
and Baigent S, 2013; Deuchande et al., 2012; Hughes et al., 2016; Pennycott and Venugopal, 2002; Voelckel et al., 1999). In chickens, neural involvement is often observed, characterized by pleomorphic lymphocyte infiltrations, which may result in macroscopically thickening of the peripheral nerves (Pattison et al., 2008). However, these neural involvement and nerve lesions are not frequently observed in turkeys (Powell et al., 1984). In our study, macroscopic and microscopic findings were not found in both the central and peripheral nervous systems.

It has also been reported that the presence of these nervous system lesions may be one of the differences between turkey Marek's disease and chicken classic Marek's disease (Hughes et al., 2016). The main findings in the classical form of Marek 's disease are wing and leg paralysis that varies depending on the nerve affected (Nair et al., 2020; Pattison et al., 2008). In the acute form, while pleomorphic lymphocyte deposits are observed in visceral organs, clinical findings have been reported to be less pronounced and deaths can increase rapidly in a few weeks, reaching up to $70 \%$ in major outbreaks (Nair et al., 2020; Pattison et al., 2008). In our study, clinical and macroscopic findings of Marek's disease in the turkeys were not as prominent as in the classical form. Besides, Marek's tumors were identified in visceral organs without brain and nerve involvement. All these indicate that Marek's disease may have an acute course in our study. Marek's disease is one of the most important tumoral diseases seen in domestic poultry in Turkey (Köküuslu 1975). Although natural infections are less common in turkeys than in chickens, experimental studies have revealed that turkeys are also susceptible to the disease (Davidson et al., 2002). Even it has been noted that the mortality rate and yield loss are very high in MD outbreaks rarely seen in turkey flocks (Davidson et al., 2002; Davidson et al., 2002). In turkeys, as Marek's disease reports are limited, it is often overlooked, as in our study. As noted by Elmubarak (1981), the fact that lesions in turkeys are less clinically and macroscopically apparent than in chickens may result in misdiagnosis, erroneous treatments, and consequently large economic losses. Furthermore, Poultry Veterinarians are advised to expand their differential diagnosis lists and resort to advanced laboratory examinations, because Marek's disease in turkeys can further increase economic losses by following an acute course as in our study.

It is well known that Marek's disease, which coexists with coligranulomatosis in our research, induces immunosuppression (Nair et al., 2020; Pattison et al., 2008). As described earlier, immunosuppression, predisposition and stress factors are critical for the development of E. coli infections. Coligranulomatosis is one of the important forms of colibacillosis (Hjarre and Wramby, 1945; Rahimi and Siavash Haghighi, 2014). It has been noted that controlling or preventing immunosuppressive agents such as Marek's disease virus, Chicken infectious anemia virus, and Infectious bursal disease virus can contribute positively to the prevention or reduction of $E$. coli infection in broiler chickens and turkeys (Nolan et al., 2020). Furthermore, it has been stated that the presence of coligranulomatosis, whose pathogenesis is not fully known, cannot be explained only by infection, and stress factors or immunosuppression may contribute to the development of this disease (Noori et al., 2011). In our study, it was concluded that immunosuppression caused by Marek's disease contributed to the transport of E. coli agents to the liver and caused the disease. On the other hand, various environmental factors and concomitant infections appear to affect the incidence of MD, possibly by interfering with immune responses (Nair et al., 2020; Pattison et al., 2008). Since MD infection can also suppress host immune responses on its own, it has been reported that it can frequently aggravate concomitant infections (Nair et al., 2020). As a consequence, mutual interaction and increased damage and immunosuppression can generally aggravate both disease processes (Nair et al., 2020). In our study, a histological picture supporting this situation was encountered. Granuloma formations have been formed to prevent the spread of agents coming to the liver to the surrounding tissue, but acute multifocal necroses invading the liver have developed with the effect of increasing immunosuppression and destruction over time. This resulted in aggravation of co-infections and increased losses.

In this study, pathological changes due to Marek's disease and coligranulomatosis co-infections were discussed in detail and it is concluded that these diseases may increase economic losses in turkey flocks. Therefore, coligranulomatosis should be included in the differential diagnosis list in hepatic granuloma cases in turkey flocks.

Nevertheless, it is important to evaluate together all the stress and predisposing factors that may contribute to the pathogenesis of this disease and the aetiologic agents that can cause immunosuppression such as the Marek's disease virus. Diagnosis of these diseases which are not frequently encountered in turkeys involves major difficulties due to unclear clinical and macroscopic findings. For this reason, histopathological examination, culture and immunohistochemical investigation are recommended for etiological diagnosis.

\section{References}

Barnes HJ NL., Vaillancourt JP., 2008. Colibacillosis. In: Saif YM FA, Glisson JR, Mc Dougald LR, Nolan LK, Barnes HJ, Swayne DE, editor. Diseases of poultry, Iowa State University Press, Ames. p. 691- 732.

Biggs PM., Nair V., 2012. The long view: 40 years of Marek's disease research and Avian Pathology. Avian Pathol, 41, 1, 3-9.

Blake-Dyke C., Baigent S., 2013. Marek's disease in commercial turkey flocks. Vet Rec, 173, 15, 376.

Calnek BW., Ubertini T., Adldinger HK., 1970. Viral antigen, virus particles, and infectivity of tissues from chickens with Marek's disease. J Natl Cancer Inst, 45, 2, 341-51.

Chauhan R., 2003. Bacterial diseases. Illustrated Special Veterinary Pathology International Book Distribution Co, UP, India.

Çiftçi, M., Çelik, İ., Tuzcu, M., Sur, E., Oruç, E., 2011. Marek Hastalığı Teşhisinde Histokimyasal ve Histopatolojik Bulguların Değerlendirilmesi. Dicle Üniv Vet Fak Derg, 2, 50-57.

Clarke LL., Beckstead RB., Hayes JR., Rissi, D. R., 2017. Pathologic and molecular characterization of histomoniasis in peafowl (Pavo cristatus). J Vet Diagn Invest, 29, 2, 237-41. 
Coles BH., 1985. Avian medicine and surgery, Blackwell Scientific Publications.

Davidson I., Malkinson M., Weisman Y., 2002. Marek's Disease in Turkeys. I. A Seven-Year Survey of Commercial Flocks and Experimental Infection Using Two Field Isolates. Avian Dis, 46, 2, 314-21.

Deuchande R., Murphy A., Otter A., Baigent S., Wood A., Irvine R., 2012. Marek's disease in turkeys. Vet Rec, 171, 602.

Elmubarak AK., J. M. Sharma., R. L. Witter., K. Nazerian., and V. L. Sanger., 1981. Induction of lymphomas and tumor antigen by Marek's disease virus in turkeys. Avian Dis, 25, 911-26.

Friedhoff KT., Kuhnigk C., Müller I., 1991. Experimental infections in chickens withChilomastix gallinarum, Tetratrichomonas gallinarum, andTritrichomonas eberthi. Parasitol Res, 77, 4, 329-34.

Hamilton C., Conrad R., 1958. Extreme mortality in Hjarre's disease (Co-ligranuloma) in chickens. J Am Vet Med Assoc, 132, 2, 84.

Haridy M., Goryo M., Sasaki J., Okada K., 2009. Pathological and immunohistochemical study of chickens with co-infection of Marek's disease virus and chicken anaemia virus. Avian Pathol, 38, 6, 469-83.

Haynes RB., Sackett D., Richardson W., Rosenberg W., Langley GR., 1997. Evidence based medicine: How to practice and teach evidence-based medicine, Churchill Livingstone Publications, New York, USA.

Hjarre A., Wramby G., 1945. Undersokninger over en med specifika granulom forlopande honssjukdom orsakad av mukoida kolibacterier (koligranuloma). Skand Veterinartidskr, 35, 449-505.

Hughes K., Archer J., Constantino-Casas F., Wozniakowski G., Baigent S., 2016. Diagnostic investigation of Marek's disease in a turkey. Vet Rec Case Rep, 4, 1, e000291.

Islam M., Fatema B., Faruk M., 2007. Hjarreâ s disease in chickens: clinical, pathological, microbiological and therapeutic findings. Bangladesh Journal of Veterinary Medicine, 49-53.

Kemp RL., Reid WM., 1966. Staining Techniques for Differential Diagnosis of Histomoniasis and Mycosis in Domestic Poultry. Avian Dis, 10, 3, 357-63.

Köküuslu C. Öİ., 1975. Evcil kanatlılarda gördüğümüz tümör çeşitleri. AÜ Vet Fak Derg, 22, 41-9.

Landman WJ., Molenaar RJ., Cian A., et al., 2016. Granuloma disease in flocks of productive layers caused by Tetratrichomonas gallinarum. Avian Pathol, 45, 4, 465-77.

Landman WJ., Molenaar RJ., Cian A., van der Heijden H. M., Viscogliosi E., 2016. Coligranulomatosis (Hjarre and Wramby's disease) reconsidered. Avian Pathol, 46, 3, 237-41.

Liebhart D., Hess M., 2018. Do we really need to reconsider coligranulomatosis (Hjärre and Wramby's disease) in poultry Avian Pathol, 47, 3, 225-6

Liebhart D., Neale S., Garcia-Rueda C., Wood A. M., Bilic I., Wernsdorf P., Jaskulska B., Hess M., 2014. A single strain of Tetratrichomonas gallinarum causes fatal typhlohepatitis in red-legged partridges (Alectoris rufa) to be distinguished from histomonosis. Avian Pathol, $43,5,473-80$.
Luna LG., 1968. Routine Staining Prosedures. Manual of histologic staining methods of the Armed Forces Institute of Pathology. 3.ed ed. McGaw-Hill Book Company, United States of America. p. 32-44.

Nair V., Gimeno I., Dunn J., Zavala G., Williams S.M., Reece R.L. and Hafner S., 2020. Neoplastic Diseases. In: Swayne DE, editor. Diseases of poultry. John Wiley \& Sons, USA. p. 548-715.

Nolan LK., Vaillancourt JP., Barbieri NL., Logue CM., 2020. Colibacillosis. In: Swayne DE, editor. Diseases of Poultry. 1. John Wiley \& Sons, USA. p. 770-830.

Noori M., Gharagozloo Mj., Azarabad H., 2011. Lymphoid Leucosis and Coligranoluma in a Budgerigar (Melopsittacus undulatus). Iran J Vet Med, 5, 1, 5-8.

Pattison M., McMullin P., Bradbury JM., Alexander D., 2008. Poultry diseases, Elsevier Health Sciences.

Patton CS., Patton S., 1996. Tetratrichomonas gallinarum encephalitis in a mockingbird (Mimus polyglottos). J Vet Diagn Invest, 8, 1, 133-7.

Paul PS., Sautter JH., Pomeroy BS., 1977. Susceptibility of turkeys to Georgia strain of Marek's disease virus of chicken origin. Am J Vet Res, 38, 10, 1653-6.

Pennycott TW., Venugopal K., 2002. Outbreak of Marek's disease in a flock of turkeys in Scotland. Vet Rec, 150, 9, 277-9.

Powell PC., Howes K., Lawn AM., Mustill B. M., Payne L. N., Rennie M., Thompson M. A., 1984. Marek's disease in turkeys: the induction of lesions and the establishment of lymphoid cell lines. Avian Pathol, 13, 2, 201-14.

Rahimi M., Siavash Haghighi ZM., 2014. An outbreak of visceral coligranuloma in a backyard chicken flock. Comp Clin Path, 23, 2, 381-4.

Ramesh G., Srinivas B., Mahesh B., Raju BV Balaeswara, Sawale GK., Rambabu, D., Lakshman M., 2018. Occurrence of Hjarre's disease (Coligranuloma) in adult layer chicken. Pharma Innov, 7, 6, 316-317.

Richter B., Schulze C., Kämmerling J., Mostegl M., Weissenböck H., 2010. First report of typhlitis/typhlohepatitis caused by Tetratrichomonas gallinarum in three duck species. Avian pathol, 39, 6, 499-503.

Schofield FW., 1947: Hjarre and Wramby Disease. Can J Comp Med Vet Sci, 11, 5, 141-3

Supartika I., Toussaint M., Gruys E., 2006. Avian hepatic granuloma. A review. Veterinary quarterly, 28, 3, 82-9.

Trylich C., Howell J., MacDonald DW., 1977. Avian coligranuloma: case histories. Can Vet J, 18, 2, 38-40.

Trylich., 1966. Coligranuloma (Hjarre's Disease) in Turkeys. Can Vet J, 7, 2, 40-2.

Voelckel K., Bertram E., Gimeno I., Neumann U., Kaleta EF., 1999. Evidence for Marek's disease in turkeys in Germany: detection of MDV-1 using the polymerase chain reaction. Acta virol, 43, 2-3, 143-7.

Wen Y., Huang Q., Yang C., Pan L., Wang G., Qi K., Liu H., 2018. Characterizing the histopathology of natural co-infection with Marek's disease virus and subgroup J avian leucosis virus in egg-laying hens. Avian Pathol, 47, 1, 83-9.

Yavuz O., Erer H., 2017. Immunohistochemical and immunocytochemical findings associated with Marek's disease virus in naturally infected laying hens. Biotech Histochem, 92, 7, 498-505. 